\title{
Typologia zabudowy mieszkaniowej wielorodzinnej w Polsce w latach 2010-2019
}

\section{Typology of multi-family residential developments in Poland in 2010-2019}

\begin{abstract}
Streszczenie
Polska architektura mieszkaniowa drugiego dziesięciolecia XXI wieku kształtowana była w oparciu o doświadczenia inwestorów i architektów związane z następstwami światowego kryzysu finansowego z 2008 roku. Boom budowlany przed kryzysem spowodował obniżenie konkurencyjności i zarazem spadek jakości architektonicznej budowanych mieszkań. Skutki kryzysu zmusiły wszystkich uczestników procesu budowlanego do wprowadzenia racjonalizacji planowanych inwestycji. Ich powodzenie zaczęło być uzależniane od jakości funkcjonalnej, budowlanej oraz estetycznej realizowanych mieszkań.

Do analizy typologii mieszkań z drugiej dekady XXI wieku zostały wzięte pod uwagę wielkie inwestycje, w których architekci w procesie projektowania w dużej mierze uwolnieni zostali od indywidualnych czynników zewnętrznych wpływających bezpośrednio na formę budynków, jak np. wąska działka budowlana i charakterystyczne wymagania planistyczne. Inwestycje tworzące całe zespoły architektoniczne lub nawet zespoły urbanistyczne pozwoliły architektom na projektowanie budynków mieszkalnych w oparciu o racjonalne założenia projektowe wynikające z potrzeb rynkowych związanych z funkcjonalnym rozkładem mieszkań oraz z potrzeb technologicznych wynikających ze sprawną realizacją budowy.
\end{abstract}

\begin{abstract}
Polish residential architecture of the second decade of the 21st century was shaped based on the experiences of investors and architects related to the consequences of the global financial crisis of 2008. The construction boom before the crisis caused a decrease in competitiveness and at the same time a decrease in architectural quality of the built apartments. The crisis forced all participants in the construction process to rationalize planned investments. Their success began to depend on the functional, construction and aesthetic quality of the constructed apartments.

For the analysis of the typology of housing of the second decade of the 21st century, large investments were taken into account, in which architects were largely freed from individual external factors directly affecting the form of the buildings, such as a narrow construction and characteristic plot planning requirements. Investments forming entire architectural complexes or even urban complexes allowed architects to design residential buildings based on rational design assumptions arising from the market needs related to the functional layout of apartments and resulting from efficient construction technologies.
\end{abstract}

Słowa kluczowe: architektura mieszkaniowa drugiego dziesięciolecia XXI, zabudowa wielorodzinna, architektura polska XXI, osiedle Keywords: residential architecture of second decade of XXI century, multi-family housing, Polish architecture of XXI century, housing estate

\section{Wprowadzenie}

1.1. Zabudowa mieszkaniowa wielorodzinna w latach 2010-2019 jako problem badawczy

Drugie dziesięciolecie XXI wieku zaowocowało w polskiej przestrzeni architektonicznej wieloma interesującymi realizacjami zabudowy mieszkaniowej wielorodzinnej. Jej lepszą jakość i większe zdyscyplinowanie w projektowaniu przestrzeni mieszkań można zawdzięczać dwóm czynnikom: pierwszym jest ukonstytuowanie się konkretnych założeń projektowych, wypracowywanych od wczesnych lat dziewięćdziesiątych minionego wieku; drugim zaś są następstwa światowego kryzysu finansowego z 2008 roku.

Od 1989 roku, kiedy w Polsce nastąpiła zmiana ustrojowa, sytuacja w budownictwie mieszkaniowym uległa całkowitemu przeobrażeniu. Dominująca w latach

\section{Introduction}

1.1. Multi-family housing development in $2010-2019$ as a research problem

The second decade of the twenty-first century resulted in many interesting multi-family housing projects in the Polish architectural space. Its better quality and the greater discipline in the design of the residential spaces can be attributed to two factors: the first is the formation of specific design assumptions, developed since the early 1990s; the second is the consequences of the global financial crisis of 2008.

Since 1989, when the political system change took place in Poland, the situation in housing construction has been completely transformed. Panel-block housing [tr.- pre-fabricated and pre-stressed concrete blocks used for panel building constructions], which 
osiemdziesiątych „wielka płyta” ustąpiła miejsca tradycyjnym metodom budowlanym, wzbogaconym nowymi technologiami, rozwijanymi w krajach zachodnich. Do procesu projektowego zostali również włączeni mieszkańcy. Układy i program mieszkań zależały od możliwości finansowych kupujących. Technologiczne standardy współczesnego typowego budownictwa mieszkaniowego wielorodzinnego wypracowano w Polsce na początku XXI wieku, jednak pod względem racjonalności konstrukcji oraz wymogów funkcjonalnych i estetycznych standardy typologii zabudowy ukształtowały się dopiero w drugim dziesięcioleciu. Paradoksalnie na coraz lepszą jakość zabudowy mieszkaniowej miał istotny wpływ światowy kryzys finansowy z 2008 roku, po którym oferta deweloperska musiała być o wiele bardziej atrakcyjna, niż w przypadku budynków realizowanych kilka lat wcześniej. Znacznie obniżona zdolność kredytowa klientów nabywających mieszkania wymuszała na nich poszukiwanie rozwiązań funkcjonalnych, w których mniejszy metraż jednocześnie mógłby zapewnić odpowiedni komfort życia. Również deweloperzy zaczęli poszukiwać oszczędności w realizacji inwestycji. Wymagało to od architektów projektowania budynków o prostych układach konstrukcyjnych i funkcjonalnych.

Uprawomocniony staje się przegląd i zabiegi systematyzujące zabudowę mieszkaniową z drugiego dziesięciolecia XXI wieku wydają się wskazane, aby lepiej zrozumieć ewolucję polskiej architektury. Być może rezultaty podjętych badań, chociaż cząstkowego spojrzenia, posłużą jako źródło strategii, pomogą rozwiązać wiele problemów, na które napotyka architekt w trakcie procesu projektowego? Umożliwią również twórcze ich wykorzystanie w procesie projektowym?

\subsection{Stan badań}

Badacz najnowszej architektury napotyka na pewne trudności, które determinuje ograniczony dostęp do literatury przedmiotu, a raczej brak szerokiego wyboru tej literatury. W tym przypadku nieoceniona staje się fachowa prasa architektoniczna, w której regularnie prezentowane są najnowsze realizacje mieszkaniowe, a także refleksje ich projektantów. Wspomnieć wypada, że w ostatnim czasie ukazało się kilka pozycji książkowych dotyczących najnowszej architektury mieszkaniowej, oraz przedstawiających problemy mieszkaniówki z tej perspektywy. Są to wprawdzie opracowania podejmujące interesujący nas temat i poruszające różne jego aspekty, lecz w większości od strony około architektonicznej, z uwzględnieniem rozległego kontekstu i odwołań do różnych dziedzin nauki. Taki charakter ma praca Agaty Twardoch System do mieszkania. Perspektywy dostępnego budownictwa mieszkalnego (Twardoch, 2019), w której wyraźnie wskazana jest konieczność nowego podejścia do mieszkalnictwa. Warto również zwrócić uwagę na następujące pozycje: Mieszkanie w zabudowie wielorodzinnej - obraz ewolucji idei projektowej, uwarunkowań rozwojowych i sposobów użytkowania dominated during the 1980s gave way to traditional construction methods, enriched with new technologies, developed in Western countries. Residents also became involved in the design process. The layouts and programme of the apartments depended on the financial capabilities of the buyers. The technological standards of contemporary typical multi-family housing were developed in Poland at the beginning of the twenty-first century. However, in terms of construction rationality, as well as functional and aesthetic requirements, the standards of building typology were formed only in the second decade. Paradoxically, the increasingly better quality of residential development was significantly influenced by the global financial crisis of 2008, after which the developers' offer had to be much more attractive than in the case of buildings constructed several years earlier. The significantly reduced creditworthiness of apartment buyers forced them to look for functional solutions in which a smaller area could provide adequate living conditions. Developers also started looking for savings in their projects. This required architects to design buildings with simple structural and functional layouts.

A review and systematisation of housing development from the second decade of the twenty-first century seems to be justified in order to better understand the evolution of Polish architecture. Perhaps the results of the study, although providing only partial insight, will serve as a basis for strategy. This might help to solve many problems encountered by architects during the design process or help to facilitate the creative aspect of design.

\subsection{The state of research}

Those who study the newest architecture encounter some difficulties which determine the limited access to the literature, or rather the lack of a wide choice of this literature. In this case, the professional architectural press, which regularly presents the latest residential projects and the reflections of their designers, becomes invaluable. It is worth mentioning that, recently, several books on the latest housing architecture have been published, which present the problems of housing from this perspective. Although these are studies that discuss topic we are interested in and touch upon its various aspects, they are mostly from an architectural point of view, taking into account the extensive context and references to various fields of science. Such is the nature of Agata Twardoch's System do mieszkania. Perspektywy dostepnego budownictwa mieszkalnego [tr. - A system for living. Prospects of affordable housing](Twardoch, 2019), in which the necessity of a new approach to housing is clearly indicated. The following works are also worth noting: Mieszkanie w zabudowie wielorodzinnej - obraz ewolucji idei projektowej, uwarunkowań rozwojowych i sposobów użytkowania na przykładzie Górnego Śląska [tr.- Multifamily housing - a picture of the evolution of the design idea, development conditions and ways of use on the example of Upper Silesia](Kucharczyk-Brus, 2016), 
na przykładzie Górnego Śląska (Kucharczyk-Brus, 2016), Uwarunkowania środowiskowe w projektowaniu obszarów mieszkaniowych" (Kobylarczyk, 2018) Nowoczesne mieszkanie (Tulkowksa-Słyk, 2019) czy Architektura wielorodzinnych domów dostępnych (Pallado, 2007) oraz liczne monografie wieloautorskie. Warto również zwrócić uwagę na publikacje Quality of Social Space in selected contemporary multifamily housing complexes in Poland's three biggest cities (Gyurkovich, M., Sotoca, 2019) oraz Living space in a city - selected problems of shaping modern housing complexes in Cracow - part 1 and 2 (Gyurkowich J., 2019). Temat współczesnego mieszkania nie jest zatem badaczom obcy, nie jest pomijany lecz dyskutowany zarówno w środowiskach naukowych, jak i zawodowych.

\subsection{Reprezentatywne przykłady}

Podstawową metodą badawczą umożliwiającą okreslenie charakterystycznych elementów typologii zabudowy mieszkaniowej jest analiza porównawcza. Aby lepiej zrozumieć logikę projektowania poddanych analizie budynków, należało wybrać przykłady, które powstały w ramach większych zespołów budynków, gdzie ograniczenia związane z konkretną lokalizacją są w tym przypadku drugorzędne, a proces inwestycyjny skoncentrowany był na tworzeniu najbardziej efektywnych mieszkań, zarówno pod względem konstrukcyjnym, funkcjonalnym, jak i estetycznym. Można przypuszczać, że właśnie w większych zespołach mieszkaniowej zabudowy wielorodzinnej architekci mogli zastosować najlepiej przemyślane docelowe rozwiązania.

Jednym z najciekawszych, dużych założeń mieszkaniowych jest 19. Dzielnica w Warszawie zaprojektowana przez pracownię JEMS architekci. Powstanie tej inwestycji zapoczątkowało zmianę jakościową w polskiej architekturze mieszkaniowej. Regularne fasady korespondujące z uporządkowanymi planami budynków stały się wzorem dla innych budynków mieszkalnych. W 2013 zrealizowane pierwsze etapy osiedla otrzymały nominację do nagrody Unii Europejskiej im. Miesa van der Rohe.

Kolejnym, poddanym analizie zespołem mieszkaniowym jest warszawskie osiedle Wilno. Jest to bardzo duże założenie realizowane przez jednego dewelopera i zaprojektowane przez pracownię Hermanowicz Rewski Architekci. Stanowi ono spójny, stworzony od podstaw zespół urbanistyczny z własną stacją kolejową i zorganizowaną przestrzenią publiczną w postaci placów, skwerów i parków. W tej samej pracowni powstał również projekt osiedla Saska w Warszawie, stanowiący samodzielnie funkcjonujący zespół urbanistyczny w niewielkiej odległości od centrum Warszawy.

Warte uwzględnienia jest duże założenie - osiedle Żoliborz Artystyczny, które zostało zaprojektowane w pracowni Mąka Sojka Architekci. Z warszawskich przykładów należy również wspomnieć o wybranych
Uwarunkowania środowiskowe w projektowaniu obszarów mieszkaniowych [tr.- Environmental conditions in designing residential areas](Kobylarczyk, 2018), Nowoczesne mieszkanie [tr.- Modern flat](TulkowksaSłyk, 2019), or Architektura wielorodzinnych domów dostepnych [tr.- Architecture of affordable multi-family houses] (Pallado, 2007), as well as numerous multi-author monographs.

It is also worth paying attention to Quality of Social Space in selected contemporary multifamily housing complexes in Poland's three biggest cities (Gyurkovich, M., Sotoca, 2019) and Living space in a city - selected problems of shaping modern housing complexes in Cracow_part 1 and 2 (Gyurkowich J., 2019). The topic of contemporary housing is therefore neither alien to researchers nor is it overlooked, but is discussed in both academic and professional circles.

\subsection{Representative examples}

The basic research method for determining the characteristic elements of housing typologies is comparative analysis. In order to better understand the design logic of the buildings under analysis, it was necessary to select examples that were created within larger building complexes, where site-specific constraints are secondary, and the development process was focused on creating the most efficient dwellings, both structurally, functionally and aesthetically. It can be assumed that it was in larger complexes of multifamily residential buildings that architects could apply the best thought-out solutions.

One of the most interesting, large residential complexes is the "19th District" in Warsaw, designed by JEMS Architekci. The creation of this project initiated a qualitative change in Polish residential architecture. Regular facades corresponding to ordered building plans became a model for other residential buildings. In 2013, the first stages of the estate were nominated for the European Union Prize for Contemporary Architecture- Mies van der Rohe Award.

Another residential complex under analysis is the Wilno housing estate in Warsaw. This is a very large project built by a single developer and designed by Hermanowicz Rewski Architekci. It is a coherent urban complex created from scratch with its own railway station and organised public space in the form of squares and parks. The same studio also designed the Saska housing estate in Warsaw, which is an independently functioning urban complex within a short distance from the centre of Warsaw.

Żoliborz Artystyczny, likewise a large development, is also worth considering. It was designed by Mąka Sojka Architekci. When further considering the examples from Warsaw, we should also mention selected city blocks built in Wilanów. Those designed by JEMS Architekci, Szymborski Architekci and Grupa 5 are particularly noteworthy.

Many housing estates have been built with much more modest budgets in the suburbs of Warsaw and its peripheral districts.. It should be emphasised that 
kwartałach zrealizowanych w Wilanowie. Na szczególną uwagę zasługują te, zaprojektowane przez JEMS Architekci, Szymborski Architekci oraz Grupa 5.

$\mathrm{Na}$ przedmieściach Warszawy i na jej peryferyjnych dzielnicach powstało wiele osiedli mieszkaniowych o znacznie skromniejszym budżecie. Podkreślić należy fakt, że jakość architektoniczna tych realizacji pod względem rozwiązań funkcjonalnych nierzadko nie ustępuje osiedlom z centrum Warszawy. Dobrymi przykładami są osiedla Sprawna na warszawskiej Białołęce czy osiedle Zielone Zamienie w gminie Lesznowola na południe od Warszawy zaprojektowane w pracowni ATI.

Z inicjatywy wrocławskich architektów i samorządowców w stolicy Dolnego Śląska powstaje osiedle Nowe Żerniki, mające pełnić rolę modelowej dzielnicy mieszkaniowej w nawiązaniu do wystawy WUWA z 1929 roku. To, co w głównej mierze odróżnia osiedle od typowych założeń deweloperskich we Wrocławiu, to z pewnością planowanie przestrzenne spajające zespół urbanistyczny w całość wraz z ofertą przestrzeni publicznej, budynkami o funkcji edukacyjnej, kulturalnej, a nawet sakralnej.

Na uwagę zasługuje również osiedle Mieszkaj w Mieście zaprojektowane przez pracownię medousagroup, stanowiące "nowy powiew" (Brataniec, 2017) na tle deweloperskich realizacji w Krakowie. Interesującym przykładem jest też osiedle Książęce w Katowicach zaprojektowane w pracowni AiR Jurkowscy Architekci, które nawiązuje do tradycji mieszkaniowej architektury modernistycznej na Śląsku (Świeżawski, 2019, s. 315).

Wśród polskich realizacji charakterystyczne wydaje się osiedle Warzelnia w Poznaniu, w którym można zaobserwować szczególną dbałość o detal architektoniczny. W latach 2010-2019 w polskiej przestrzeni miejskiej pojawiła się nowa forma mieszkania. Jest nią mikro-apartament. Po doświadczeniach pierwszych realizacji warto się przyjrzeć tej formie, która w przyszłości może znacznie wpłynąć na charakter przestrzeni miejskiej.

\section{Charakterystyka problematyki wielorodzinnej zabu- dowy mieszkaniowej z lat 2010-2019}

\subsection{Lokalizacja a jakość architektury}

W historii powojennej architektury mieszkaniowej lokalizacja inwestycji nigdy nie miała takiego wpływu na charakter i jakość architektury jak w drugim dziesięcioleciu XXI stulecia. Dobrze zaprojektowane osiedla powstawały zarówno w centrach miast, jak i na przedmieściach. W czasach gdy cena gruntu, w tym jego uzbrojenia i rewitalizacji, zbliża się często do kosztów budowy deweloper oferuje coś więcej niż racjonalną architekturę, aby uzasadnić wysoką cenę mieszkań. Warszawskie realizacje są najbardziej spolaryzowane. W latach 2010-2019 coraz wyraźniej zauważalny jest podział na architekturę "bogatych" apartamentowców budowanych w zasięgu infrastruktury centrum stolicy i masową produkcję mieszkań z przedmieść szybko rosnącej aglomeracji z ceną mieszkań poniżej umownej granicy 10000 zł/m². the architectural quality of these developments is often just as good in terms of functional solutions as those in the centre of Warsaw. The Sprawna estate in Warsaw's Białołęka or the Zielone Zamienie estate in the Lesznowola municipality to the south of Warsaw, designed by tATI, are good examples.

At the initiative of Wrocław architects and local government officials, the Lower Silesian capital is developing the Nowe Żerniki estate, which is to serve as a model residential district in reference to the 1929 WUWA exhibition. What distinguishes the housing estate from the typical development assumptions in Wrocław is certainly its spatial plan which joins the urban complex together with public spaces, buildings with educational, cultural and even religious functions.

Also noteworthy is the Mieszkaj w Mieście estate, designed by medusa group, which is a "new breeze"(Brataniec, 2017) against the background of other developer projects in Cracow. Another interesting example is the Książęce housing estate in Katowice, designed by AiR Jurkowski Architects, which refers to the tradition of Modernist residential architecture in Silesia (Świeżawski, 2019, p. 315).

Among Polish projects, the Warzelnia estate in Poznań seems to be quite distinct, with an observable attention to architectural detail.

In the years 2010-2019, a new form of housing appeared in Polish urban space. It is the micro-apartment. After the experiences from the first projects, it is worth to investigate form, which may significantly affect the character of urban spaces in the future.

\section{Characteristics of multi-family residential devel- opment issues between 2010 and 2019}

\subsection{Location and architectural quality}

In the history of post-war residential architecture, the location of a project has never had such an impact on the character and quality of architecture as in the second decade of the twenty-first century. Well-designed housing estates have been built both in city centres and in the suburbs. At a time when the price of land, including its development and revitalisation, often comes close to construction costs, the developer offers more than rational architecture to justify the high price of the apartments. Warsaw projects are the most polarised. In the years 2010-2019, the division between the architecture of the "rich" apartment buildings built within the infrastructure of the capital city centre and the mass production of flats in the suburbs of a rapidly growing agglomeration, with the price of flats below the conventional boundary of PLN 10,000 per square meter, became more and more noticeable.

The former group is usually characterised by individual solutions with a budget for above-standard design solutions, which are allowed by very high apartment prices, caused by demand and lack of available places for larger residential projects, often built on revitalised areas. One can find good qual- 
Tę pierwszą grupę cechują zwykle indywidualne rozwiązania z przewidzianym budżetem na ponadstandardowe rozwiązania projektowe, na które pozwalają bardzo wysokie ceny mieszkań, spowodowane popytem i brakiem dostępnych miejsc dla większych inwestycji mieszkaniowych, realizowanych często na rewitalizowanych terenach. Można tu spotkać dobrej jakości materiały wykończeniowe, starannie zaprojektowane podwórka i hole wejściowe, duże przeszklenia i okładziny na elewacjach. Często o formie budynków w mniejszych zespołach decyduje spełnienie minimum dostępu do naturalnego światła, a nie logika struktury czy wypracowane proporcje formy architektonicznej.

Druga grupa charakteryzuje się bardziej racjonalnymi rozwiązaniami małych mieszkań, dedykowanych klientom o mniejszej sile nabywczej. Deweloperska „optymalizacja" sięga każdego elementu budynku. Trudno tam spotkać dobrze rozwiązane przestrzenie wspólne, jak choćby przestronne i solidnie wykończone hole wejściowe. Wielkość okien wynika z technologicznych ograniczeń najcieńszych ram z profili z PCV i wymaganego doświetlenia światłem dziennym. Okładziny na elewacjach wypiera coraz rzadziej boniowany - w stosunku do poprzednich dwóch dziesięcioleci - malowany tynk i styropian najgorszej jakości. Solidne okładziny z cegły klinkierowej lub szarej betonowej częściej spotkać można w śląskich czy poznańskich osiedlach, niż na warszawskich przedmieściach.

Zróżnicowanie architektury przedmieść często nadal wynika z dość przypadkowych zapisów w warunkach zabudowy i zagospodarowania terenu lub planach zagospodarowania przestrzennego, choć te drugie są nieliczne. Brak racjonalnego planowania rozwoju aglomeracji, jej infrastruktury, szczególnie komunikacyjnej i społecznej, będzie miał ogromny wpływ na jakość życia mieszkańców przedmieść.

2.1. Deweloper - konserwatywny kreator potrzeb klientów Deweloperzy, których głównym celem jest wysoki i szybki zysk, gwarantowany przez masową "produkcję” powtarzalnych układów mieszkań, boją się ryzyka. Ich postrzeganie potrzeb potencjalnych klientów uzależnione jest w praktyce od opinii kierowników działów sprzedaży, zwykle niezorientowanych w kierunkach rozwoju współczesnej architektury mieszkaniowej oraz logice projektowania dobrych przestrzeni wspólnych i tych wewnętrznych - prywatnych. Wszystkie nietypowe czy bardziej awangardowe pomysły architektów są odrzucane już na etapie koncepcji. Wszak ich intencją jest szybkie "sprzedanie" klientowi nie przygotowanemu do odbioru współczesnej architektury stwarza w oczach dewelopera kolejne niepotrzebne ryzyko wydłużenia czasu obrotu pieniądza.

Wzorce wypracowane przez drugie dziesięciolecie naszego wieku doprowadziły do optymalizacji każdego elementu budynku: od układów mieszkań, komunikacji, konstrukcji żelbetowej po grubość profilu ramy okiennej ity finishing materials, carefully designed courtyards and entrance lobbies, large glazing and cladding on facades. Often, the form of the buildings in smaller complexes is determined by the minimum access to sunlight and not by the logic of the structure or the proportions of the architectural form.

The second group is characterised by more rational solutions of small apartments, dedicated to customers with lower purchasing power. The developers' "optimisation" affects every element of the building. It is difficult to find well-designed common spaces, such as spacious and well finished entrance halls. The size of the windows results from the technological limitations of the thinnest frames made of PVC profiles and the required daylight. The cladding on the facade is replaced by less and less often rusticated-compared to the previous two decades-painted plaster and Styrofoam of the worst quality. Solid clinker brick or gray concrete cladding can be found more often in Silesian or Poznań housing estates than in Warsaw's suburbs.

The diversity of suburban architecture often still results from quite accidental entries in planning decisions or local spatial development plans, although the latter are few in number. Lack of rational planning of the agglomeration's development, its infrastructure, especially circulation and social infrastructure, will have a huge impact on the quality of life in the suburbs.

2.1. Developer-a conservative creator of customer's needs

Developers, whose main goal is high and quick profit, guaranteed by the mass "production" of repeatable layouts of apartments, are afraid of risk. In practice, their perception of the needs of potential customers depends on the opinions of sales department managers, usually uninformed in the directions of the development of contemporary residential architecture and the design logic of creating good common and internal private spaces. All unusual or more avant-garde ideas of the architects are rejected at the conceptual stage. After all, their intention is to quickly "sell" to a client who is not prepared for contemporary architecture. In the eyes of the developer, this creates another unnecessary risk of extending the time of money turnover. Patterns developed by the second decade of our century have led to the optimisation of every element of the building: from the apartment layouts, circulation, reinforced concrete structure to the thickness of the window frame profiles or glazing. Most materials are selected for a ten-year warranty period, which can be compared to the production of cars designed for several years of operation. The next generations of users will have to face the low durability of insulation and finishing materials.

\subsection{Functional layouts designed after the financial crisis of 2008}

In the residential architecture of the "post-crisis" period, simple rational building structures based on the 


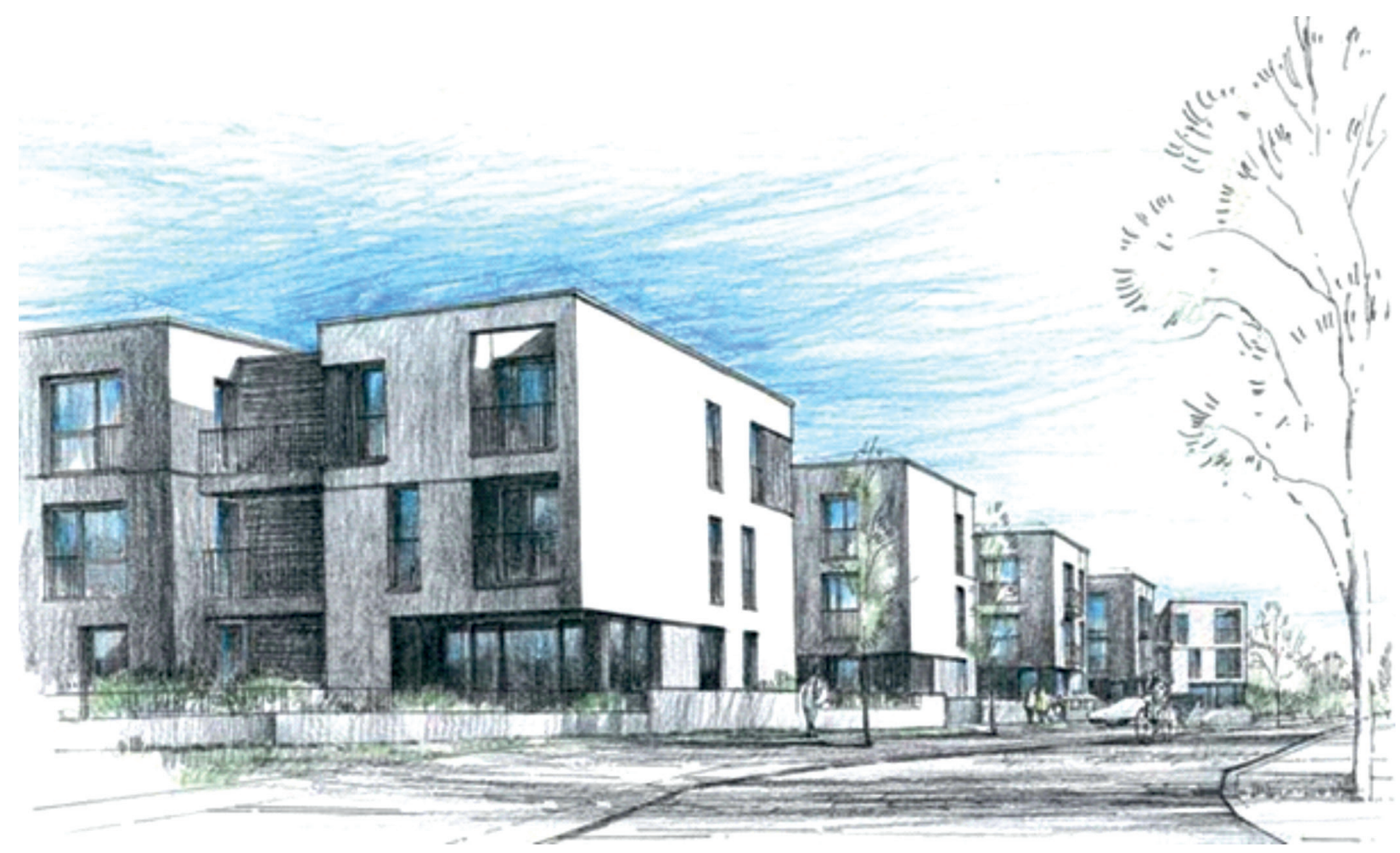

il. 1. Perspektywa osiedla Sprawna w dzielnicy Białołęka w Warszawie (proj. ATI) Zaproponowane nietypowe mieszkania, pomimo że funkcjonalnie rozwiązane, były sprzedawane znacznie dłużej niż standardowe mieszkania - źródło: ATI

ill. 1. Drawing of the Sprawna housing estate in the Białołeka district in Warsaw (ATI design) The proposed atypical flats, although functionally resolved, were sold much longer than standard flats - source: ATI

czy szklenia. Większość materiałów dobranych jest do dziesięcioletniego okresu rękojmi, co można porównać do produkcji samochodów zaprojektowanych na kilka lat funkcjonowania. Z niską trwałością izolacji i materiałów wykończeniowych będą musiały się zmierzyć kolejne pokolenia użytkowników.

\subsection{Układy funkcjonalne budynków projektowane po} kryzysie finansowym z 2008 roku

W architekturze mieszkaniowej okresu „pokryzysowego" przeważają proste racjonalne struktury budynków opartych na najprostszych układach mieszkań. Zauważalny jest odwrót od tradycyjnej zabudowy po obwodzie kwartałów, generującej sekcje z dwoma, trzema lub czterema mieszkaniami dostępnymi z jednej klatki. Deweloperzy unikają droższej w realizacji zabudowy na trakcie o szerokości $12 \mathrm{~m}$ z funkcjonalnie zaprojektowanymi mieszkaniami dwustronnymi w układzie północ-południe, z klasycznym strefowaniem na część dzienną i nocną. Poszukiwane są tereny i kwartały o idealnej orientacji północ-południe, umożliwiającej realizację tańszej zabudowy o głębszych traktach głębokości około $16 \mathrm{~m}$ z jednostronnymi mieszkaniami w układzie korytarzowym, gdzie jedna klatka schodowa może obsługiwać do kilkunastu mieszkań na kondygnacji.

W pozostałych przypadkach na terenach o nie idealnej orientacji lub kształcie tradycyjna zabudowa kwartałów zastępowana jest przez zwarte budynki punktowe z pięcioma lub nawet ośmioma mieszkaniami obsługiwany- simplest apartment layout prevail. A retreat from traditional buildings built along the perimeter of city blocks is noticeable, generating building divisions with two, three or four apartments accessible from one staircase. Developers avoid the more expensive construction of a 12-metre wide development with functionally designed two-sided apartments in a north-south layout, with classic zoning for day and night. The developers seek areas and quarters with an ideal north-south orientation, which enable the construction of cheaper buildings with deeper bays, about 16 metres deep, with one-sided flats in a corridor layout, where one staircase can support up to a dozen flats on one floor.

In other cases, in areas with a less than perfect orientation or shape, traditional buildings are replaced by compact point buildings with five or even eight flats served by one circulation division. Optimisation of building blocks with limited facade area and circulation has an impact on the urban layout and the quality of the apartments themselves. Urban layouts are generated by area indicators and simple building blocks rarely allows for good zoning of public and semi-public spaces.

Optimised circulation and corridor building layouts determine the increasingly simpler layouts of onesided, two- and three-room apartments, which are dominated by dark kitchen annexes. Bright kitchens used to be typical even in a two-room panelblock flats in Ursynów, in the second decade of the 
mi przez jeden pion komunikacyjny. Optymalizacja brył budynków z ograniczeniem powierzchni elewacji i komunikacji ma wpływ na urbanistykę i jakość samych mieszkań. Urbanistyka generowana przez wskaźniki powierzchni i proste bryły budynków rzadko pozwala na dobre strefowanie przestrzeni publicznych i pół-publicznych.

Optymalizowanie powierzchni komunikacji i korytarzowe układy budynków determinują coraz prostsze układy jednostronnych mieszkań dwu- i trzypokojowych, w których dominują ciemne aneksy kuchenne. Jasne kuchnie niegdyś typowe nawet dla dwupokojowych mieszkań wielkiej płyty z Ursynowa, w drugiej dekadzie naszego stulecia spotkać można przeważnie tylko w mieszkaniach narożnych. Coraz bardziej liberalne liberalizowane prawo podąża za optymalizacją deweloperów. Zlikwidowane zostały zapisy o minimalnej szerokości pokojów czy szesnastometrowej powierzchni salonów. Jednoprzestrzenne mieszkania bez wydzielonych kuchni czy jadalni reklamowane są jako integrujące rodziny. Przy średniej powierzchni mieszkań dwupokojowych 35-40 m² oraz 50-55 m² mieszkań trzypokojowych te zabiegi wydają się zbędne.

\subsection{Mikro-apartamenty - hotel czy jeszcze mieszkanie?}

W trudnych czasach po kryzysie pojawił się nowy typ "mieszkań inwestycyjnych”, przeznaczonych dla młodych, mobilnych pracowników bez zdolności kredytowej. Renesans zaczęły przeżywać rozwiązania siedemnastometrowych kawalerek, charakterystycznych dla warszawskiego Żoliborza robotniczego, pamiętane przez pradziadków pokolenia "Z", współcześnie powracające z nową nazwą "mikro-apartamentów” na wynajem. Przedrostek „mikro" znika w folderach deweloperów wraz z pojawieniem się wydzielonego przesuwnymi drzwiami aneksu sypialnego w "apartamencie” o powierzchni 25$30 \mathrm{~m}^{2}$. Idea mobilnych czy ażurowych przegród zastępujących tradycyjne ściany była już obecna w architekturze Sadów Żoliborskich Haliny Skibniewskiej czy żoliborskich willach. Nigdy jednak mieszkania nie były tak ograniczone powierzchniowo. Ta nowa forma "apartamentowego" mieszkalnictwa stanowi coraz większy odsetek mieszkań sprzedawanych w Warszawie i innych aglomeracjach.

\subsection{Technologia a rynek pracowników budowlanych}

Doświadczenia inwestycji z czasów „po kryzysie”, realizowanych często przez deweloperów i ich podwykonawców bez kredytowania miały wpływ na świadomość technologii i kosztów budowy. Dogłębna analiza poszczególnych elementów budynku wpłynęła na ich strukturę, bryłę i detal architektoniczny.

Najlepszym przykładem racjonalizacji kosztów budowy jest poszukiwanie oszczędności w konstrukcji. Niskie koszty pracy $w$ ostatnich latach praktycznie wyeliminowały z polskich budów elementy prefabrykowane. Ogromny napływ pracowników zza wschodniej granicy pozwolił na kontynuowanie i rozwój pracochłonnych i energochłonnych technologii budowy, prawie zapo- twentieth century, and can now mostly be found only in corner apartments. Increasingly liberalised law is following the optimisation practiced by the developers. The provisions requiring a minimum width for rooms or a sixteen-metre living room have been removed. Single-space flats without separate kitchens or dining rooms are advertised as "integrating families". With an average surface area of 35-40 $\mathrm{m}^{2}$ two-room apartments and $50-55 \mathrm{~m}^{2}$ three-room apartments, these treatments seem unnecessary.

\subsection{Micro-apartments-a hotel or an apartment?}

In the difficult times after the crisis, a new type of "investment apartments" appeared, designed for young, mobile workers without creditworthiness. Designs of seventeen-meter studios, characteristic of Warsaw's Żoliborz workers' district, remembered by the great-grandparents of generation Z, now return under the new name of "micro-apartments" for rent. The prefix "micro" disappears in the developers' folders with the appearance of a sleeping annex separated by a sliding door in a 25-30 $\mathrm{m}^{2}$ "apartment". The idea of mobile or openwork partitions replacing traditional walls was already present in the architecture of Halina Skibniewska's Sady Żoliborskie or Żoliborz villas. However, apartments have never been so limited in size. This new form of "apartment" housing is an increasing percentage of the flats sold in Warsaw and other agglomerations.

\subsection{Technology and the construction workers' market}

The experience of projects from the "post-crisis" times, often built by the developers and their subcontractors without credit, has had an impact on their awareness of technology and construction costs. An in-depth analysis of individual building elements influenced their structure, shape and architectural detail.

The best example of rationalising construction costs is looking for savings in construction. Low labour costs in recent years have practically eliminated prefabricated elements from Polish construction sites. The huge influx of workers from across the eastern border has allowed the continuation and development of labour-intensive and energy-intensive construction technologies, almost forgotten in Western Europe.

The beginning of the second decade of the twentyfirst century was clearly dominated by the use of mixed skeleton-wall systems based on complex structural systems with perimeter ribs, limiting the thickness of floors. Smaller floor spans adapted to the module of two parking spaces have allowed for further, significant savings on steel compared to the modules of three parking spaces prevalent in the previous decade. Most of the walls were made of Silka or ceramic blocks. The inter-apartment walls of the 
mnianych w krajach Europy Zachodniej.

$\mathrm{Na}$ początku drugiego dziesięciolecia XXI wieku zdecydowanie dominowały mieszane układy szkieletowo-ścienne oparte na skomplikowanych układach konstrukcyjnych z żebrami obwodowymi, ograniczających grubości stropów. Mniejsze rozpiętości stropów dopasowane do modułu dwóch stanowisk parkingowych pozwoliły na dalsze, znaczne oszczędności w zużytej stali w stosunku do modułów trzech stanowisk dominujących w poprzednim dziesięcioleciu. Większość ścian murowano z bloczków Silka lub ceramicznych. Ściany międzymieszkaniowe drugiej i trzeciej, ostatniej kondygnacji często zastępowały droższy żelbet.

Wszystkie te optymalizacje miały ogromny wpływ na zwiększenie zysku deweloperów, ale nie na zmniejszenie kosztów mieszkań. Docelowy klient otrzymywał produkt mniej uniwersalny, trudniejszy do modyfikacji w przyszłości w porównaniu z układami szkieletowymi o większych rozpiętościach stropów. Polskie projekty znacznie różnią się od rozwiązań stosowanych w innych krajach europejskich. Dla porównania w Skandynawii od XX wieku stosuje się prefabrykowane dziewięcio- lub nawet dwunastometrowej rozpiętości stropy z kanałowych płyt sprężonych (często produkowanych w Polsce).

Przez ostatnie trzy lata nastąpił ponad pięćdziesięcioprocentowy wzrost kosztów pracy, co miało ogromny wpływ na zmianę technologii budowy. W kolejnych inwestycjach zaczęto wprowadzać coraz więcej elementów prefabrykowanych: najpierw balkonów, potem biegów klatek schodowych. Ścianki murowane działowe i między-mieszkaniowe z drobnowymiarowych bloczków Silka czy ceramicznych zostały wyparte przez większe bloczki gipsowe, niewymagające tynkowania. Można zaobserwować szybki odwrót od pracochłonnych robót mokrych na budowie. Wspomnieć warto, że wynagrodzenie rzędu 40 zł/h obciążone składką ZUS, odbiega od stawek w krajach Europy Zachodniej czy Skandynawii, gdzie doświadczony montażysta na budowie zarabia 75 Euro za godzinę. W budownictwie trzeciego dziesięciolecia można spodziewać się całkowitego odejścia od robót mokrych i renesansu polskiej prefabrykacji w całkowicie nowej formie.

\subsection{Struktura uniwersalna. Budownictwo a ślad węglowy} Współczesne polskie budownictwo mieszkaniowe i jego ograniczenia technologicznie wynikające z poszukiwania oszczędności, nie pozwala na modyfikacje w przyszłości. Konstrukcja i instalacje nie są uniwersalne. Ściany zewnętrzne często są elementem konstrukcji, a okna nie posiadają modularnego rozstawu. Ograniczona do minimum wysokość kondygnacji uniemożliwi w przyszłości zmianę funkcji lub wyposażenia instalacyjnego. Czas życia wielu budynków będzie krótki a ich demontaż i recyrkulacja materiałów kosztowna i energochłonna. Budynki i deweloperzy w żaden sposób nie są oceniani za jakość struktury budynków, a ich klienci nie uwzględniają krótszego okresu amortyzacji i zużycia mieszkań, które kupują. Prawo budowlane, sposób opodatkowania second and third, last floor often replaced the more expensive reinforced concrete.

All these optimisations had an immense impact on increasing the developers' profit, but not on reducing the cost of the apartments. The target customer received a less versatile product, more difficult to modify in the future compared to the skeletal systems with larger floor spans. Polish designs differ significantly from the solutions used in other European countries. For comparison, in Scandinavia, prefabricated nine- or even twelve-meter span floors made of precast concrete slabs (hollow core units or HCU) (often manufactured in Poland) have been used since the twentieth century.

Over the last three years, there has been more than a $50 \%$ increase in labour costs, which has had a profound impact on the change in construction technology., An increasing number of prefabricated elements entered use in subsequent projects: first, balconies, then staircase runs. Brick partition and inter-apartment walls made of small-size Silka blocks or ceramic blocks have been replaced by larger gypsum blocks that do not require plastering. One can observe a quick retreat from labour-intensive wet works at construction sites. It is worth mentioning that a salary of PLN 40/h charged with the necessary social insurance fees (ZUS), differs from the rates in Western Europe or Scandinavia, where an experienced fitter earns EUR 75 per hour. In the construction works of the third decade, one can expect a complete departure from wet works and a renaissance of Polish prefabrication in a completely new form.

\subsection{Universal structure. Construction and the carbon footprint}

The contemporary Polish residential construction sector and its technological limitations resulting from the search for savings do not allow for future modifications. Structural systems and building services are not universal. Exterior walls are often a part of the structure, and the windows do not have a modular spacing. The floor height, limited to a minimum, will prevent future changes in the function or building service equipment. The lifetime of many buildings will be short, and their disassembly and recirculation of the materials will be expensive and energy consuming. Buildings and developers are by no means evaluated based on the quality of the structure of the buildings, and their clients do not take into account the shorter period of depreciation and usage of the apartments they buy. Construction law, taxation and government support should, however, follow the concern for the quality of the environment in which its citizens live.

The next decade will probably bring greater awareness of the carbon footprint, not only in the field of energy and the automotive industry, but also in the way of nutrition, transportation, as well as in construction. Support for technologies using 


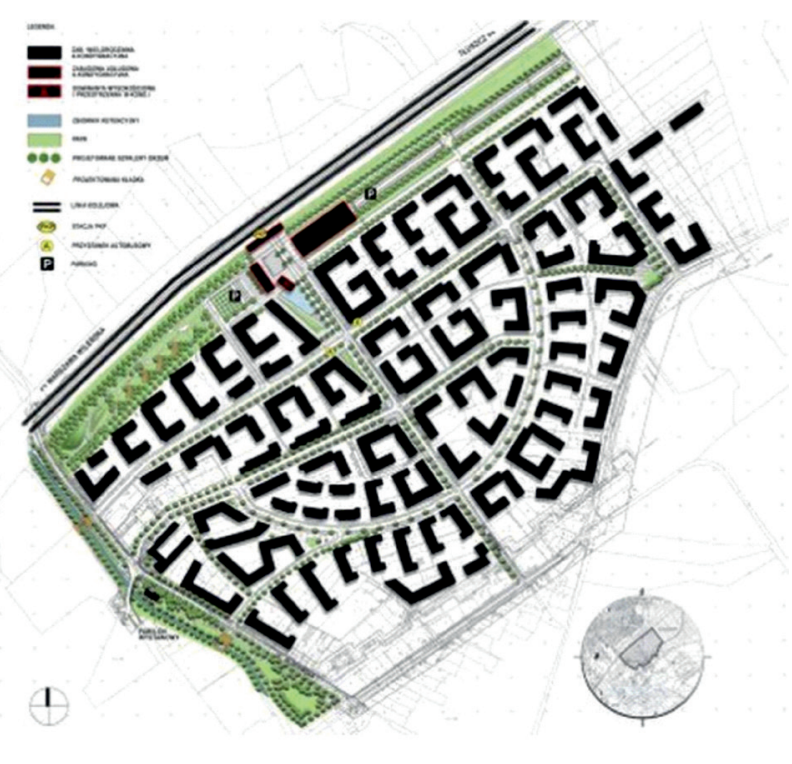

i wsparcie rządowe powinny jednak podążać za troską o jakość środowiska, w którym żyje człowiek.

Kolejne dziesięciolecie zapewne przyniesie większą świadomość śladu węglowego nie tylko w dziedzinie energetyki czy przemyśle motoryzacyjnym, ale i w sposobie odżywiania, komunikacji, a także w budownictwie. Można spodziewać się wsparcia dla technologii wykorzystujących rozwiązania niskoenergetyczne i proekologiczne.

\section{Podsumowanie}

Doświadczenia drugiego dziesięciolecia XXI wieku w polskim budownictwie mieszkaniowym, u jego początków były skoncentrowane na skutkach światowego kryzysu finansowego z 2008 roku. Kryzys nie był jedynym czynnikiem, ale w istotny sposób wpłynął na kształt (ewolucję i rozwój) polskiego budownictwa. Śledząc realizacje deweloperskie powstałe $w$ tym okresie można zauważyć wiele pozytywnych następstw, które zostały wymuszone przez trudności w finansowaniu inwestycji. Pierwszą i zarazem najważniejszą zmianą w stosunku do początków naszego wieku było pojawienie się większej konkurencyjności na polskim rynku mieszkaniowym. W ten sposób proces inwestycyjny zaowocował o wiele lepszą jakością architektury i wspólnej przestrzeni osiedli.

$\mathrm{Na}$ początku drugiego dziesięciolecia w polskich miastach zaczęło również brakować terenów inwestycyjnych. Ten problem wymusił na wielu deweloperach działania, które pozwoliły wykorzystać zaniedbane niegdyś tereny lub przygotować kompleksowo nowe działki. W ten sposób rozpoczęła się rewitalizacja wielu obszarów poprzemysłowych. Jednocześnie pojawiło się planowanie osiedli w większej skali. Najlepszym przykładem wydaje się osiedle Wilno, w którym deweloper wybudował stację kolejową, aby lepiej skomunikować osiedle z centrum Warszawy.

Firmy deweloperskie oraz architekci położyli większy nacisk na lepszą organizację procesu projektowego oraz il. 2. Projekt urbanistyczny osiedla Wilno w dzielnicy Targówek w Warszawie (proj. Hermanowicz Rewski Architekci) - źródło: www.sztukaarchitektury.pl

ill. 2. Urban design of the Wilno estate in the Targówek district in Warsaw (designed by Hermanowicz Rewski Architekci) - source: www.sztukaarchitektury.pl

low energy and pro-ecological solutions can be expected.

\section{Conclusion}

The experience of the second decade of the twentyfirst century in Polish housing, at its beginning was focused on the effects of the global financial crisis of 2008. The crisis was not the only factor but it significantly influenced the shape (evolution and development) of the Polish construction sector. Following the development projects built in this period, one can notice many positive consequences, which were forced by difficulties in financing of the projects. The first and also the most important change compared to the beginning of this century was the emergence of greater competitiveness on the Polish housing market. In this way, the real estate development process resulted in a much better quality of architecture and common spaces of the residential developments.

The beginning of the second decade, also saw a shortage of buildable areas in Polish cities. This problem forced many developers to take action which allowed the use of once neglected areas or comprehensive preparation of new plots. In this way, the revitalisation of many post-industrial areas began. At the same time, planning of larger-scale housing appeared. The best example is the Wilno estate, in which the developer built a railway station to better connect the estate with the centre of Warsaw.

Developers and architects have put more emphasis on better organising the design process and construction itself. Optimisation activities also aimed to accelerate the real estate development process, which was to guarantee greater profits. Savings were sought in every field, and following the improving economic situation, housing construction turned to the latest technologies. 
samej budowy. Poszukiwanie oszczędności w każdym zakresie zmierzały również do przyspieszenia procesu inwestycyjnego, co miało zagwarantować większe zyski. Oszczędności poszukiwano na każdym polu, a w ślad za polepszającą się sytuacją gospodarczą budownictwo mieszkaniowe zwracało się w stronę najnowszych technologii.

\section{BIBLIOGRAFIA}

[1] Brataniec, M., 2017 Zespół MIESZKAJ W MIEŚCIE w Krakowie, Architektura-Murator, 11/2017;

2] Gyurkovich, J. 2019 Living Space in A City - Selected Problems of Shaping Modern Housing Complexes in Cracow- A Multiple Case Studies: Part 1 - The Case Study of Urban Villas. IOP Conference Series: Materials Science and Engineering, Volume 471, Issue 9. Dostępny w: https://iopscience.iop.org/ article/10.1088/1757-899X/471/9/092015 [dostęp: 10.04.2020]

[3] Gyurkovich, J. 2019 Living Space in A City - Selected Problems of Shaping Modern Housing Complexes in Cracow - A Multiple Case Studies: Part 2-The Case Study of High Density Forms of Multi-Family Residential Buildings. IOP Conference Series: Materials Science and Engineering, Volume 471, Issue 9 Dostępny w: https://iopscience.iop.org/article/10.1088/1757-899X/471/9/092016 [dostęp: 10.04.2020]

[4] Gyurkovich, M., Sotoca, A. 2019 Quality of Social Space in selected contemporary multifamily housing complexes in Poland's three biggest cities. IOP Conference Series: Materials Science and Engineering, Volume 471, Issue 9. Dostępny w: https://iopscience.iop.org/article/10.1088/1757-899X/471/9/092009 [dostep: 10.04.2020]

[5] Kobylarczyk, J.,2018 Uwarunkowania środowiskowe w projektowaniu obszarów mieszkaniowych, Kraków: Wydawnictwo Politechniki Krakowskiej;

[6] Kucharczyk-Brus, B.,2016 Mieszkanie w zabudowie wielorodzinnej - obraz ewolucji idei projektowej, uwarunkowań rozwojowych i sposobów użytkowania na przykładzie Górnego Śląska, Gliwice: Wydawnictwo Politechnika Śląska;

[7] Łącki, S., Malicka, W., Malicki, Z. 1961 Budownictwo mieszkaniowe, Warszawa : Wydawnictwo Arkady:

[8] Pallado, J. 2007 Architektura wielorodzinnych domów dostępnych, Katowice: Wydawnictwo Śląsk:

[9] Świerzawski, J. 2019 Przemiana W: B. Stelmach, L. Andrzejewska-Batko red. Tożsamość. 100 lat architektury polskiej, Warszawa: Narodowy Instytut Architektury i Urbanistyki:

[10] Tulkowska-Słyk, K. 2019 Nowoczesne mieszkanie, Warszawa: Oficyna Wydawnicza Politechniki Warszawskiej;

[11] Twardoch, A. 2019 System do mieszkania. Perspektywy rozwoju dosteppnego budownictwa mieszkalnego, Warszawa: Bęc Zmiana.

\section{REFERENCES}

[1] Brataniec, M., 2017 Zespół MIESZKAJ W MIEŚCIE w Krakowie, Architektura-Murator, 11/2017.

[2] Gyurkovich, J. 2019 Living Space in A City - Selected Problems of Shaping Modern Housing Complexes in CracowA Multiple Case Studies: Part 1- The Case Study of Urban Villas. IOP Conference Series: Materials Science and Engineering, Volume 471, Issue 9. Dostępny w: https://iopscience.iop.org/article/10.1088/1757-899X/471/9/092015 [dostęp: 10.04.2020]

[3] Gyurkovich, J. 2019 Living Space in A City - Selected Problems of Shaping Modern Housing Complexes in Cracow - A Multiple Case Studies: Part 2 - The Case Study of High Density Forms of Multi-Family Residential Buildings. IOP Conference Series: Materials Science and Engineering, Volume 471, Issue 9. Dostepny w: https://iopscience.iop.org/article/10.1088/1757-899X/471/9/092016 [dostęp: 10.04.2020]

[4] Gyurkovich, M. Sotoca, A. 2019 Quality of Social Space in selected contemporary multifamily housing complexes in Poland's three biggest cities. IOP Conference Series: Materials Science and Engineering, Volume 471, Issue 9. Dostępny w: https://iopscience.iop.org/article/10.1088/1757-899X/471/9/092009 [dostęp: 10.04.2020]

[5] Kobylarczyk, J.2018 Uwarunkowania środowiskowe w projektowaniu obszarów mieszkaniowych, Kraków: Wydawnictwo Politechniki Krakowskiej;

[6] Kucharczyk-Brus, B.,2016 Mieszkanie w zabudowie wielorodzinnej - obraz ewolucji idei projektowej, uwarunkowań rozwojowych i sposobów użytkowania na przykładzie Górnego Śląska, Gliwice: Wydawnictwo Politechnika Śląska;

[7] Łacki, S., Malicka, W., Malicki, Z. 1961 Budownictwo mieszkaniowe, Warszawa: Wydawnictwo Arkady;

[8] Pallado, J. 2007 Architektura wielorodzinnych domów dostepnych, Katowice: Wydawnictwo Śląsk

[9] Świerzawski, J. 2019 Przemiana W: B. Stelmach, L. Andrzejewska-Batko red. Tożsamość. 100 lat architektury polskiej, Warszawa: Narodowy Instytut Architektury i Urbanistyki;

[10] Tulkowska-Słyk, K. 2019 Nowoczesne mieszkanie, Warszawa: Oficyna Wydawnicza Politechniki Warszawskiej:

[11] Twardoch, A. 2019 System do mieszkania. Perspektywy rozwoju dostępnego budownictwa mieszkalnego, Warszawa: Bęc Zmiana. 